Finisterra, XXXIII, 65, 1998, pp. 117-128

\title{
SUBSTATE NATION-BUILDING AND GEOGRAPHICAL REPRESENTATIONS OF 'THE OTHER' IN GALICIA, SPAIN (1860-1936)
}

\author{
JACOBO GARCÍA-ÁLVAREZ ${ }^{1}$
}

\begin{abstract}
The 'social construction' of otherness and, broadly speaking, the ideological-political use of 'external' socio-spatial referents have become important topics in contemporary studies on territorial identities, nationalisms and nation-building processes, geography included. After some brief, introductory theoretical reflections, this paper examines the contribution of geographical discourses, arguments and images, sensu lato, in the definition of the external socio-spatial identity referents of Galician nationalism in Spain, during the period 1860-1936. In this discourse Castile was typically represented as 'the other' (the negative, opposition referent), against which Galician identity was mobilised, whereas Portugal, on the one hand, together with Ireland and the so-called 'Atlantic-Celtic nationalities', on the other hand, were positively constructed as integrative and emulation referents.
\end{abstract}

Key-words: Nationalism, nation-building, socio-spatial identities, external territorial referents, otherness, Spain, Galicia, Risco, Otero Pedrayo, Portugal, Atlantism, pan-Celtism.

Résumé: LA CONSTRUCTION D’un NATIONALISME SOUS-ETATIQUE ET LES REPRESENTATIONS GEOGRAPHIQUES DE “L'AUTRE” EN GALICE, ESPAGNE (1860-1936) - La formation de toute identité est un processus dialectique et dualiste, en tant qu'il implique la manipulation et la mobilisation de la "différence" à travers des stratégies d'inclusion et d'exclusion. La conscience de l'identité collective propre s'active et se renforce, notamment au moyen de la reconnaissance d'un "autre", face auquel le fait différentiel se met en mouvement. Le processus de construction idéologique et politique de la "communauté imaginée" nationale que font les nationalismes agit à travers un double discours: d'une part celui de l'intégration et de l'autre celui de la différence; on utilise aussi, fréquemment, des réferentiels socio-territoriaux extérieurs dans un sens aussi bien négatif et séparateur (autonomismes politiques, indépendantismes) que positif et intégrateur (expansionismes, irrédentismes, recherche d'alliés internationaux, etc.). Ce texte expose le rôle des arguments, images et représentations géographiques, sensu lato, dans les référentiels territoriaux extérieurs qui font partie du discours nationaliste de la Galice en Espagne entre 1860

1 Departamento de Geografía, Universidad Autónoma de Madrid, 28049 - Madrid, Spain. E-mail: jacobo.garcia@uam.es 
et 1936. Dans ce système, la Castille a été présentée comme la principale référence d'opposition (l'“autre" contre lequel on mobilise l'identité galicienne) tandis que le Portugal, d'un côté, l'Irlande et les "nationalités celtiques" (l'Écosse, la Bretagne, le pays de Gales), de l'autre, étaient les références positives d'intégration et d'émulation (lusitanisme, atlantisme, pan-celtisme).

Mots-clés - Nationalisme, construction nationale, identités socio-spatiales, référents territoriaux extérieurs, alterité, Espagne, Galice, Risco, Otero Pedrayo, Castille, Portugal, lusitanisme, atlantisme, pan-celtisme.

Resumo: A CONSTRUÇÃO DE UM SUBESTADO NAÇÃO E AS REPRESENTAÇÕES GEOGRÁFICAS DO “OUTRO" NA GALIZA, ESPANHA (1860-1936) - A formação de toda a identidade sócio-territorial constitui um processo dialéctico e dual, pois implica a manipulação e mobilização da diferença mediante estratégias de inclusão e de exclusão. A consciência da identidade colectiva própria (o "nós"), activa-se em larga medida, e intensifica-se pelo reconhecimento de um Outro (o "eles"), face ao qual mobiliza o facto diferenciador. Os processos de construção ideológica e política da "imaginada comunidade" nacional, levados a efeito pelos nacionalismos, desenvolvem-se através de um duplo discurso (o da integração e o da diferença), e utilizam com frequência referentes sócio-territoriais exteriores, tanto em sentido negativo e de separação (autonomismos, independentismos), como também no sentido positivo e integrador (expansionismos, irredentismos, busca de aliados internacionais, etc). Neste estudo expõe-se brevemente o contributo de argumentos, de imagens e de representações geográficas, em sentido lato, na definição do sistema de referentes territoriais exteriores, desenvolvido pelo discurso nacionalista galego, entre 1860 e 1936. No quadro desse sistema, Castela foi apresentada como o principal referente negativo ou de oposição (isto é, o "outro", contra o qual se mobiliza a própria identidade galega), enquanto Portugal, por um lado, a Irlanda e as chamadas "nacionalidades célticas" (Escócia, Bretanha, País de Gales, etc), por outro, eram os referentes positivos de integração e de emulação (lusitanismo, atlantismo, panceltismo).

Palavras chave: nacionalismo, construção nacional, identidades sócio-territoriais, referentes territoriais exteriores, alteridade, Espanha, Galiza, Risco, Otero Pedrayo, Portugal, lusitanismo, atlantismo, panceltismo.

\section{1 - INTRODUCTION. NATIONS, NATIONALISM AND THE IDEA OF OTHERNESS}

In the last two decades, there has been a growing interest among scholars from various fields in unravelling the 'imagined' (ANDERSON, 1983/1991), 'historical' (PAASI, 1986), 'narrative' (BHABHA, 1990), 'discursive' (CABRERA, 1992) and - broadly speaking - 'socially constructed' (MURPHY, 1991; JACKSON and PENROSE, 1993) dimensions of nations, political boundaries and territorial communities. Nations - is stated, for instance, in the well-known Benedict Anderson's work - do constitute 'imagined communities', in the sense that "the members of even the smallest nation will never know most of their fellow-members, meet them, or even hear of them, but in the minds of each lives the image of their communion" (ANDERSON 1991: 6). That 
means, without denying, they can have a powerful 'ethnic' material bases (shared language, territory, economic relations, historical traditions, and so on), nations are also to a great extent culturally and ideologically created; they are largely constructed and represented trough discourses, narratives, etc. to come into being in the consciousness of their habitants as 'real', coherent socio-spatial units.

Nationalism and its ideologues play thus a prominent 'creative' role. No matter how solid might be that ethnic material base, nations are not revealed and imagined as such, becoming politically meaningful, but trough the action of an intelligentsia responsible for: $a$ ) Isolating and gathering the distinctive identity features of their own community together within coherent discursive totalities, thus defining the ' $\mathrm{We}$ '; $b$ ) Mobilising them against other community which comes to be considered to a more or lesser extent external, hence defining the 'Other'; and $c$ ) Endowing those discursive totalities with a political-institutional organisation oriented to gain a popular support and autonomous political status. It can then be said that, rather than being the nation which constructs nationalism, it is nationalism which constructs the nation, politically elaborating the available 'raw material' and articulating a collective identity.

The idea of Otherness is probably as ancient and universal as human culture, and it has became a major topic, too, in contemporary reflections on the nature of collective identities, international relations, etc. (for geography, see for instance SAID, 1978; DALBY, 1988; PAASI, 1998). Scholars know well how much, ontologically, the formation of all socio-spatial identity is an inherently dialectic, dualistic process involving the manipulation of boundaries and the mobilisation of difference for strategies of inclusion and exclusion: opposite to the 'we', it is necessary to define the 'other'; opposite to the 'here', we must define the 'there'(SHORE, 1993; PAASI, 1996). "Consciousness of the We becomes possible and is developed (...) by recognising the Other" (Lisón, 1993: 41-42). As Paasi puts it, "the spatial dimension is implicit in the construction of Otherness, since the Other typically lives elsewhere, the "there"' (PAASI, 1998).

Hence two sort of opposed, complementary discourses or languages are dialectically displayed: on the one hand, the language of integration (i.e., the socio-spatial pair 'we/here'); on the other hand, the language of difference (i.e., the socio-spatial pair 'they/there'). "The former aims at homogenising the contents of spatial experience, the latter strives to distinguish this homogenising experience from the Other" (PAASI, 1996: 15). To a more or lesser extent, nationalism (the symbolic discursive process of construction of national socio-spatial identities) necessarily involves these two discourses, therefore its ever-conflictive political potential.

On the other hand, the use of external territorial referents in order to construct or reinforce the definition of the own national identity cannot be reduced to the negative, separatist construction of the 'other'. Nation-building projects, strategies and political claims may centrally mobilise another sort of identity socio-spatial pair, that is, the 'we/there', with an integrative language and intention: either to incorporate a social community beyond their own territorial boundaries (expansionism, irredentism), or simply to gain external, international allies and supporters which share common interests and goals. 
When looking into these matters within particular empirical contexts, as in the case here studied, remarkable questions concerning the general theme of this issue the circulation of ideas in the history of geographical thought do directly and exemplarily arise, e.g: geography's active participation in, and contribution to, nationalist discourses and movements; intellectual transfers and imports from the academic disciplinary cores of a time (in this case the modern Ratzelian-Vidalian schools in interwar Europe) to comparatively speaking peripheral contexts (here Galicia in Spain); the use, spread, exchange, and reshape of general discourses and currents (such as nationalism, environmentalist regional geography, etc.) through different, even competing sociospatial scales (e.g., local, substate vs state nationalisms); the search for, and the development of, external and, specifically, suprastate and international(ist) identity attachments from within locally or regionally-based discourses on difference, etc.

\section{2 - NATIONALISM AND GEOGRAPHY IN GALICIA, 1860-1936}

The rise and development of competing discourses on regional and national identities, as well as on the territorial organisation of State, do constitute, both culturally and politically, one of the main, conflicting processes in 1860-1936' Spain (MOLINERO and SMITH, 1996). Opposite to the liberal, 'state' version of Spanish nationalism, held by the ruling elites and crucially inspired by the French-revolutionary ideas, some regional, 'substate' nationalisms did vividly emerge during this period, primarily drawing upon the German Romantic conceptions of nation. This was specially the case of three geographically peripheral northern regions (Catalonia, Basque Country and Galicia) in which indigenous languages other than Castilian were spoken by the majority of country people. It is necessary to remark that, during the first half of the nineteenth century, Spanish State governments had established not only a highly centralised model based on a new Territorial Division Act (1833), by which the former administrative unity of the old historical kingdoms (thus Galicia and Catalonia too) were split in several provinces, but also a uniform national system of education in which the use of non-Castilian languages was not allowed.

Having started as a non-political, basically cultural, regionalist revival (literary use of indigenous language, writing of regional history, etc.), all these three peripheral movements evolved to a political nationalism between 1890 and 1936, establishing their own parties and gaining an increasingly ample - but never hegemonic, except from in Catalonia - social support. Furthermore, their growing dynamics led the Spanish state to an open-ended process of political decentralisation during the period 19311936, which was dramatically stopped by the beginning of the Civil War and the establishment of Franco dictatorship.

In a previous article (GARCíA ÁlVAREZ, 1998), I have tried to expound the intense, even prominent relationships between geographical thought, territorial arguments and images, and substate nationalism in the specific context of Galicia during the period 1860-1936 (for the general history of Galician nationalism, see BERAMENDI, 1991; MAÍZ, 1994; BERAMENDI and NÚÑEZ, 1995). 
Inspired by the Romantic conception of nations as well as by the powerful influence of natural sciences on the social thought and disciplines of the time, Galicianist main ideologues defined and located the essences of Galician regional/national identity in 'natural', physical realities which they regarded to be much more 'determinant', 'lasting' and 'tangible' that the 'socially-constructed', 'ever-changing' and 'abstract' dynamics of politics. In this respect, the undeniable linguistic (being language considered as a 'natural' faculty) and territorial distinctiveness of Galicia opposite to the Spanish central regions (its peripheral coastal location, Atlantic bioclimate, mountainous topography, granitic morphology, eastern orographical boundaries, etc.) provided Galicianism with two decisive arguments. As important as them was the idea of an original racial individuality (the so-called 'Celtic myth'), historically unlikely but intentionally developed by Galicianists as a way of displacing internal class-contradictions between Galicians to a second plane; reinforcing the designation of the other in the Spaniards from the centre and south (presented as 'Semitic' people); and claiming to a broader, European Aryan link (MURGUíA, 1865-1913).

Whereas regional poets (R. de Castro, E. Pondal) and historians (B.Vicetto, M. Murguía) were the main leaders of the cultural 'resurgence' (rexurdimento) of Galicia during the last nineteenth-century third, geography and geographical discourse will take a prominent role during the period 1920-1936, just when Galicianism reached to organise a very active institutional framework of parties and political groupings (unified in the so-called Galicianist Party, 1931-1936), scientific associations, editorials and journals, and a remarkable electoral support. As it was the case of many other states (HoOsON, 1994) and even of other well-known substate communities (e.g., GARCÍA-RAMON and NOGUÉ, 1994, for Catalonia; GRUFFUDD, 1994 and 1995, for Wales) under the vivid nationalist background of 1870-1940 Europe, geography was invested by Galicianists with an explicit patriotic meaning and did actively contribute to the definition of the own national identity - the 'we'.

On the one hand, personally and institutionally, the promotion of regional geographical knowledge and arguments within the discursive construction of Galician identity was mainly due to the work of two figures, Vicente Risco (1884-1963) and Ramón Otero Pedrayo (1888-1976), directly involved in the main ideological, cultural and political expressions of pre-war Galicianism (BOBILLO, 1981; QUINTANA, and VALCÁRCEL, 1988). They both extensively knew the ideas of contemporary geographical tradition -particularly Ratzelian and Vidalian Schools-, and Otero in particular, Geography teacher at the Secondary School of Ourense, took on task of writing the very first modern synthesis on Galician regional geography (OTERO, 1926a and 1928; PÉREZ,1987).

On the other hand, material conditions of Galician territory and economy (e.g, in the beginning of the twenties peasantry still represented ninety per cent of its working population) decisively favoured the penetration of ruralist, environmentalist ideas and approaches dominant in geography at that time. As I tried to show in the reference above quoted, the 'geographical construction' of Galician national identity did comprise a wide range of subjects and arguments, all around the 'man-environment' 
and the 'regional concept' central concerns: it was the deep historical interpenetration between an ethnos ('raza') and a geographical milieu ('terra') which for Galicianists created the so-called volkgeist or national culture, whose essences were argued to remain pure and untouched within the peasantry language and way of life (OTERO, 1933). Clearly delimited from other Spanish neighbouring regions by landscape and morphotectonical features, Galicia was systematically presented not only as a linguistic but also 'natural geographical region' whose reality should not be longer politically denied (RISCO, 1920).

\section{3 - THE 'OTHER' AND THE 'BROTHERS': EXTERNAL TERRITORIAL REFERENTS OF GALICIAN NATIONALIST DISCOURSE. CASTILE, PORTUGAL, IRELAND AND THE 'CELTIC LANDS'}

Galicianist discourse does also represent, in exemplary fashion, the use of external socio-spatial referents in order to strengthen the national 'we' referent (Galicia), as well as to endow its substate nationalist ideal not only with other peripheral 'allies' in Spain but also with an international territorial project and support. Since the time of literary and historiographical rexurdimento, Castile, Catalonia, the Basque Country, Portugal and Ireland -the last one together with the so called 'Celtic nationalities'- became frequented nodes within the conceptual-semantic networks of oppositions/associations through which this discourse was constructed. In three of these cases (Castile, Portugal and the Celtic referents), geographical arguments and images did meaningfully contribute again.

a) CASTILE - the large Iberian central region, the medieval kingdom which led the process towards the founding of modern Spanish state, the geographical setting of the capital and state central institutions, the nucleus of the unique official language at that moment -, rather than the Spanish state, appeared for Galicianism as the negative 'other', the reference against which the national 'we' was somehow mobilised. However, never did Galicianism officially claim for a political separation of the state, since the Galicianist Party preferred political aim was the achievement of a federal or confederate organisation, composed by what they regarded to be the five 'Iberian nationalities': Portugal, Castile, Catalonia, Galicia and Basque Country. With regard to our particular subject of study, it is remarkable how this 'opposition referent' embodied in Castile was to a great extent also presented in racial and territorial-landscape terms: not only were Castilianmen regarded to be holders of African, Semitic blood (hypothesis already used by Murguía, besides being commonly accepted at the time), hence different Galician (European, Aryan) race; but also, opposite to the extolled natural beauties of Galicia, Castilian climate and landscape would be constantly depicted with sour, negative words.

It was regional literature in fact which first developed and exploited this kind of territorial images. Right from two of the most well-known poems of Rosalía de Castro, published in 1863, Castilian plains are described as if they were 'ugly', 'miserable', 
'desolated', 'dusty', 'never-ending deserts', being even compared with 'Hell', in contrast to the 'pleasant', 'happy', humid, evergreen, fertile, densely peopled landscapes of her motherland, for which she suggested the simile of a 'paradise' (CASTRO, 1863). Furthermore, by appealing to a symbolic analogy commonly used in Romantic literature, as well as in environmental determinism academics, so the moral character of Castilian people was presented as miserable, harsh, dry and austere as their landscape.

From travel-books and tourist-guides to geography treatises and textbooks, the description of the access to Galicia coming from the former general 'road of Castile', through the pass of La Canda (a stretch where the flashy, objective landscape contrasts existing between these two regions were quickly and sharply revealed), it soon became at that time one of the most frequented topics for presenting not only the geographical distinctiveness of this sector of the Iberian Peninsula, but also its extolled 'aesthetical superiority' (see for instance MURGUÍA, 1888; PEDREIRA, 1894; OTERO, 1926b). The multiple social problems of Galician peasantry were eventually cornered when evoking, comparatively to Castilia, the 'kindness' of its landscape; in most of these representations, Galicia typically becomes a sort of 'idyllic landscape' (locus amoenus) where local and foreign travellers do 'recover' from the sadness that Castilian 'waste landscape' (locus eremus) inspires them.

b) Just contrary to the case of Castile, PORTUGAL personified the main external positive, 'integration referent' of Galicianism. This being due, basically, to the strong, well-known historical and linguistic links existing between the two communities from the medieval ages (Galicianist saw Portugal as a former 'twin brother' of Galicia that had separated and reached his adult age by gaining the political independence of the Castilian crown), geographical arguments were added to complement these reasons. Nationalists used to highlight, for instance, the physical-geographical continuity existing between both territories in the borderland drained by the Minho as a way of arguing the 'political artificiality' of this division, opposite to the 'orders of Nature', as well as to claim for the re-establishment of that ancient 'brotherhood' in all possible fields (RISCO, 1921a). 'Galicia, ethnographically as well as geographically and linguistically', said Otero before the Spanish Parliament, 'is a prolongation of Portugal, or Portugal is a prolongation of Galicia, it makes no difference' (OTERO, 1931). Furthermore, when pointing at this linguistic and geographical continuity between both areas, Galicianists leaders used to externalise a collective 'sense of place' which, according to them, was much more closer to Portugal than to their Spanish neighbouring regions:

"When a Galicianman enters the plains of León or Zamora - says, for instance, Alfonso Rodríguez Castelao - he feels to be in an alien land, overcome by the sadness that deserts do inspire. If entering Asturias, he has to get his eyes used to a new style of landscape. But when he crosses the Portuguese border, he feels as in his own land, and he does not believe in the arbitrariness of historical politics (...) It cannot be expected that 
the Minho river, 'old father of Galicia', is going to last more time as a boundary between two states (CASTELAO, 1944/1986: 41-42).

Although its ideological program initially urged a sort of federal re-unification of the two main Iberian states (thus accepting the participation of Spanish central institutions), political Galicianism evolved along the twenties towards the proposal of more direct, unilateral formulas of approaching between Galicia and Portugal. Fluid cultural links between Galicianist leaders and some Portuguese intellectuals, specially around the journals Nós (Ourense) and A Águia (Porto), were developed in fact (CASTRO PÉREZ, 1985: 289-295).

The 'natural region' concept, combined with various former historical references, was also discursively mobilised in order to pose certain irredentist claims. Galicianist Party aimed to achieve the (re)incorporation to Galicia of various areas which were administratively located in other Spanish provinces (e.g.: the Land of Sanabria, in the province of Zamora; the small region of Bierzo, in the province of León; the coastal fringe between the Eo and Navia rivers, in the province of Oviedo), alleging either they were linguistically Galician, or they had belonged to the historical Kingdom/province of Galicia existing before the 1833's Territorial Division Act. Furthermore, the geographical-morphotectonical reference of the Douriensis-Galician Massif (the large natural region 'revealed' in the beginning of this century by the geologist Paul Choffat) together with another ancient historical reference (the Roman province of Gallaecia, whose territorial limits basically coincided with the mentioned Massif), were also 'ideologised' in an integrative sense, since both references included the Portuguese northern territories above the Mondego river (that is, the former administrative provinces of Trás-os-Montes and Entre-Douro e Minho) (OTERO, 1933: 45-47).

The use of such an ancient, ambitious territorial reference in Galicianist discourse did not constitute, however, much more than an idealist, nostalgic desideratum; a very attractive 'proof' to add to the geohistorical demostration of Galicia; and a soft, open 'political' invitation which came to be included in the Action Program for Galicianist Groups approved by the Second General Assembly of the Galicianist Party, in 1933:

"Historical and natural Galicia is not completely comprised within the boundaries of current administrative Galicia. The Bierzo, Sanabria, as well as the lands drained by the Portuguese Minho are all Galician. Its Galicianness should be preserved by stimulating a cordial exchange." (cf. CASTRO PÉREZ, 1985: 304). 
c) European 'CELTIC NATIONALITIES', specially IRELAND, formed an essential 'analogical or emulation referent' for Galicianists. Scientifically, this was supposed to be based, above all, on the racial affinities detected by some historians (e.g., Thierry) and anthropologists (e.g., Pitett) during the second half of the nineteenth century in different areas of Europe; whereas ideologically and politically, the Atlantism and pan-Celtism of Galicianist authors served not only to establish an historical foundational myth and a fashionable basis for the distinction from the other Spanish peoples (the non-Aryan) (QUINTANILLA, 1923), but also to locate the Galician case in the midst of a wider, international network of references: Ireland, Brittany, Cornwall, Wales, the (Scottish) Highlands and the isle of Man - i.e., what Galicianists explicitly called, together with their own region, the 'Celtic Atlantic fatherlands' of Europe. At the time of Risco and Otero, pan-Celtism was intentionally exploited to gain the ideological support of those territories, as well as to put Galician case in the same footing to them in order to achieve from the Society of Nations its nominal recognition as a 'national minority' within the Spanish state - an objective that was fulfilled in September 1933. For Galicianists, the Irish case attracted a special interest over the rest, since the almost complete political independence this nation had gained in the first $20^{\text {th }}$ century twenties.

The 'Celtic connection' theory was first developed by Murguía in the 1860s drawing on archeological, historical and ethnographical bases, and Otero Pedrayo invested it with explicit, objective - together with strong mythical-symbolic geographical meanings in one of his most well-known works (OTERO, 1933, see also 1932). Theoretically inspired by Hegelian Philosophy of History (HEGEL, 1837), Otero interpreted the agrarian historical stability, as well as the multiple landscape affinities existing between the so-called 'ethnically Celtic' areas of Europe (Britanny, Ireland, Scotland, Wales and Galicia too), to be the result of a 'total', even 'aprioristic' conjunction achieved between an specific ethnos (here the Celtic) and a specific type of landscape. What is more, all those geographical coincidences (the Atlantic coastal location and bioclimate; the presence of Palaeozoic, granitic, largely peneplained massifs; the dispersion of the population settlements - a feature that Meitzen, the German geographer, had stated to be distinctive of Celtic peoples -; the patterns of the land-property and tenancy; the contemporary continuity of a strong agrarian socio-economic basis, in the midst of an increasingly urban-industrial world, etc.) did evoke, according to him, the biblical myth of 'the promise land'.

"The very first idea of Galicia", states Otero, "appeared in History when from a remote, original and ignored land the first Celtic migrants did depart. The first vague, nebulous, elementary idea of Galicia, as well as of Britanny, and Ireland, and Scotland (...) and of all the Celtic fatherlands" (OTERO, 1933: 34-35).

In other words, for the Galician geographer those peoples presumably had within their minds a primigenious landscape ideal, which they 'pursued' through their long, historical migrations until they finally found it and settle down on it. Just as a well- 
known Spanish philosopher wrote at that time when commenting the aforementioned work of Hegel, 'peoples do emigrate in search of their akin landscape, which deep down their soul it has been promised to them by God: the promised land is the promised landscape' (ORTEGA, 1931/1973: 119). Brittany, Eire, Cornwall, Scotland, Wales and Galicia... were - and had been since the very first times, Otero claimed - an authentic 'dream-landscape', the 'promise land(scape)' of Celtic peoples. Geographical imagination hence was strategically mixed with the exemplary language of religion, in order to reinforce nationalist ideals: Galicia did constitute 'the promised land for Galicianmen', and not until they pollitically owned it 'would Galician culture completely fulfil its destiny' (OTERO, 1929). A mixture of scientific and symbolicmythical arguments can also be found in an earlier work of Risco (1921b) on the geographical relationships between Ireland and Galicia, which he started by drawing the attention to a supposed ancient, pre-glaciar orographic bridge between the two lands, whose existence had been proposed by some naturalists (as Cornide, Forbes, Beaumont, Borlasse, Mac Andrew) since the end of the eighteenth century.

No matter were they "real" or symbolic, rigorously founded or just imagined, all those geographical, landscape comparisons helped vividly in fact to project the cultural identity referents of Galicia beyond the territorial circles of the Spanish state. Nationalist ideology was thus strengthened with an international, Europeanist label which directly concerned the geographical imagination. "There is no other landscape in Spain as European as ours"- Galicianists frequently highlighted (RISCO, 1920: 28). "Its relationships, its major landscape concomitances cannot be looked for within (the rest of) Spain", argued Otero (1928: 46), whose works used to delight, in his characteristic poetical style, on what he called "the amazing insularity of Galicia".

Acknowledgements: To Josefina Gómez Mendoza, Rafael Mata Olmo, Elia Canosa, João Carlos Garcia and Luis Galiana for their valious suggestions and comments on the draft version of this paper.

\section{REFERENCES}

ANDERSON, B. (1983/1991) - Imagined communities. Reflections on the origin and spread of nationalism, revised edition. Verso, London.

BERAMENDI, J. G.(1991) - El Partido Galleguista y poco más. Organización e ideologías del nacionalismo gallego en la II República. In BERAMENDI, J.; R. MAÍZ (comps.), Los nacionalismos en la España de la II República. SigloXXI, Madrid.

BERAMENDI, J. G.; X. M. NúÑEZ (1995) - O nazonalismo galego. A Nosa Terra,Vigo.

BHABHA, H. (ed.) (1990) - Nation and narration. Routledge, London.

BoBILlo, F. (1981) - Nacionalismo gallego. La ideología de Vicente Risco. Akal, Madrid.

CABRERA, J.(1992) - La nación como discurso. La estructura del sistema ideológico nacionalista. El caso gallego. Siglo XXI-CIS, Madrid.

CAStelaO, A.R. (1944/1986) - Sempre en Galiza. Vigo, Galaxia. 
CASTRO, R. de (1863/1981) - Cantares gallegos. Akal, Madrid.

CASTRO PÉREZ, X.(1985) - O galeguismo na encrucillada republicana. Diputación Provincial, Orense, vol. 1.

DALBY, S. (1988) - Geopolitical discourse: the Soviet Union as the Other. Alternatives, XIII: 415-442.

GARCÍA ÁLVAREZ, J. (1998) - The geographical construction of a substate national identity: the Galician case in Spain, 1920-1936. Nordia Geographical Publications, Oulu, 27 (1): 38-58.

GARCÍA-RAMON, M.D; J. NOGUÉ (1994) - Nationalism and Geography in Catalonia. In HoOsON, D. (ed.): 197-211.

GRUFFUDD, P. (1994) - Back to the land: historiography, rurality and the nation in interwar Wales, Transactions of the Institute of British Geographers NS, 19: 61-77.

GRUFFUDD, P. (1995) - Remaking Wales: nation-building and the geographical imagination, 1925-50. Political Geography, 14 (3): 219-239.

HEGEL, G.W.F. (1837/1974) - Lecciones sobre la filosofía de la Historia Universal. Revista de Occidente, Madrid.

Hooson, D. (ed.) (1994) - Geography and national identity. Blackwell, Oxford.

HouZARD, G. (1993) - Diversité des formations végetales primitives et des bioclimats de l'Arc Atlantique. Norois, Poitiers, 153: 109-125.

JACKSON, P.; J. PENROSE (eds.) (1993) - Constructions of race, place and nation. UCL Press, London.

LISÓN, C. (1993) - Identidad: collage cultural. Las múltiples voces de la identidad. In ÁvILA, R.; T. CALVO (eds.) - Identidades, nacionalismos y regiones. Universidad de Guadalajara, Guadalajara.

MAíz, R. (1994) - The open-ended construction of a nation: the Galician case in Spain. In BERAMENDI, J.; R. MAíz; X.R. NÚÑEZ (eds.), Nationalism inEurope. Past and present. Universidad de Santiago, Santiago, vol. 2.

Molinero, M.C.; A. SMITH, (eds.) (1996) - Nationalism and the nation in the Iberian Peninsula. Competing and conflicting identities. Berg, Oxford (USA).

MurguíA, M.M. (1865-1913) - Historia de Galicia. Vols. I-II edited by Soto Freire, Lugo; vols. II-IV-V by E.Carré, La Coruña.

MuRGUíA, M.M. (1888/1982) - Galicia, Xerais, Vigo.

MuRPHY, A.B. (1991) - Regions as social constructs: the gap between theory and practice. Progress in Human Geography, 15 (1): 22-35.

ORTEGA Y GASSET, J.(1931/1973) - En el centenario de Hegel. In Kant, Hegel, Dilthey, Revista de Occidente, Madrid: 101-126.

OTERO PEDRAYO, R. (1926a) - Sintese xeográfica de Galicia. Lar, La Coruña.

Otero Pedrayo, R.(1926b) - Guía de Galicia (Geografía. Historia. Vida económica. Literatura y Arte. Itinerarios completos por ferrocarril y carretera). Espasa-Calpe, Madrid.

Otero PedRAyo, R. (1928) - Paisajes y problemas geográficos de Galicia. Compañía Iberoamericana de Publicaciones, Madrid. 
OTERO PEDRAYO, R.(1929) - A terra prometida. A Nosa Terra, 236: 2-3.

OTERO PEDRAYO, R. (1931) - In Diario de Sesiones de las Cortes, 41 (18-IX): 1023.

Otero Pedrayo, R. (1932/1983) - Morte e resurrección. In Obras Selectas. Ensaios, II. Galaxia, Vigo.

OTERO PEDRAYO, R. (1933) - Ensayo histórico sobre la cultura gallega. Nós, Santiago.

PAASI, A. (1986) - The institutionalization of regions: a theoretical framework for understanding the emergence of regions and the constitution of regional identity. Fennia 164: 105-146.

PAASI, A. (1996) - Territories, boundaries and consciousness. The changing geographies of the Finnish-russian border. John Wiley, Chichester.

PAASI, A. (1998) - The changing pedagogies of space: representation of the Other in Finnish school geography textbooks. In BUTTIMER, A.; S. BRUNN (eds.): Text and image: constructing regional knowledges, Institut für Länderkunde, Leipzig.

Pedreira TAiBo, L. (1894) - El regionalismo en Galicia (Estudio crítico). Tipografía La Linterna, Madrid.

Perez AlBerti, A. (1987) - A Xeografia en Otero Pedrayo. A Nosa Terra, extraodinario núm. 8, Vigo.

QuintanA, X.R.; M. VAlCÁRCEL, (1988) - Ramón Otero Pedrayo. Vida, obra e pensamiento. Ir Indo, Vigo.

QUINTANILLA, J. (1923) - Razas loiras e razas morenas. Nós, 15: 5-6.

RISCO, V. (1920) - Teoria do nacionalismo galego. La Región, Orense.

RisCO, V.(1921a) - Portugal e Galiza. Nós, 2: 8-11.

Risco, V. (1921b) - Irlanda e Galiza. Nós, 8: 18-20.

SAID, E. (1978) - Orientalism. Routledge and Kegan Paul, London.

SHORE, C. (1993) - Inventing the "people's Europe": critical approaches to European Community "cultural policy". Man, 28 (4): 779-800. 